\title{
GREEN PROCUREMENT IMPLICATIOS ON THE LABOR MARKET IN THE GONTEXT OF THE TRANSITION TO THE GREEN ECONOMY
}

\author{
Daniela Paşnicu ${ }^{1 *}$ and Vasilica Ciucă ${ }^{2}$ \\ ${ }^{1)}$ National Scientific Research Institute for Labor and Social Protection \\ (INCSMPS), Spiru Haret University (USH), Bucharest, Romania. \\ ${ }^{2)}$ National Scientific Research Institute for Labor and Social Protection \\ (INCSMPS), Bucharest, Romania.
}

Please cite this article as:

Pașnicu, D. and Ciucă, V., 2020. Green Procurement Implications on the Labor Market in the Context of the Transition to The Green Economy. Amfiteatru Economic, 22(53), pp. 28-41.

\section{Article History}

Received: 30 September 2019

Revised: 24 November 2019

Accepted: 25 December 2019

\section{DOI 10.24818/EA/2019/53/28}

\begin{abstract}
The adoption of green procurement has implications on the labor market because of the changes that occur in the economic structure. The purpose of the article is to contribute to a better understanding of the concept and policies regarding green procurement as well as the implications on the Romanian labor market of the transition to the green economy through green procurement. In this regard, several analyses have been made; an analysis of the current situation, a forecast, on secondary data, of the main trends of the Romanian labor market, compared with those of the EU28, a regression between the number of green jobs and the environmental protection expenditure as well as a cluster analysis in EU 28 countries to capture SMEs' perceptions of resource efficiency and green markets. The analysed data comes from official statistics of EUROSTAT, to which we have added the data from CEDEFOP and those collected within Eurobarometer 381. From the analysis of the data it turned out that there are certain structural imbalances in the labor market in Romania, which could be accentuated by implementing green procurement; a positive relationship at EU level between environmental protection expenditure and green jobs and insignificant differences between countries on green markets and resource efficiency.
\end{abstract}

Keywords: labor market, green procurement, over-qualification, employment, need for work, green jobs.

JEL Classification: J, J21, Q, Q57

\footnotetext{
* Corresponding author, Daniela Pașnicu - danielapasnicu@ yahoo.com
} 


\section{Introduction}

Green procurement is an instrument of both economic and environmental policy for structuring and managing the transition to a green economy. The objective of adopting green procurement is to create a market for environmentally friendly goods that will lead to improving the quality of the environment with a positive impact on human health and longterm economic growth. As part of a broader move towards sustainable forms of production and consumption, this tool will support market players in seeking and investing in the most efficient solutions.

Adopting green procurement in connection with other ecological policies and instruments will have a number of consequences that involve transforming the economic structure into less polluting and more economically efficient activities, with an impact on competitiveness and innovation. It is important to know if the Romanian labor market is prepared to support a green procurement process without major negative effects. The analyses undertaken in the article offer a characterization of the Romanian labor market, an anticipation and a better understanding of how structural changes in the economy through the adoption of green procurement can reconfigure the labor market.

The first section of the article presents the conceptual and political complexity of ecological procurement and the importance given in the literature to the implications of adopting this instrument on the labor market, from the theoretical context analysed. The indicators and methods of analysis, respectively secondary data analysis, regression analysis and multivariate cluster analysis, are described in section two. The comparative analysis of the trends currently existing in the labor market, and the employment forecasts undertaken in the third section of the article have the role to underline the specificities of the Romanian labor market and the changes that may occur in the level and structure of employment and demand on activity sectors and occupations. In order to capture the causal effect mentioned in the title and the similarities and differences between EU28 countries in supporting SME participation in public procurement tenders that include environmental requirements and green jobs created, the previous analysis was supplemented by an analysis of the correlation between green jobs and environmental protection expenditure and a cluster analysis of SMEs' perceptions from the perspective of ecological markets and resource efficiency.

\section{Review of the scientific literature}

\subsection{Green procurement: concept and policies}

Green public procurement (GPP) is defined in the Communication from the European Commission (COM (2008) 400) as a process by which public authorities wish to purchase goods, services and works with a reduced impact on the environment, throughout their entire life cycle. They are an important tool to achieve the goals of environmental policy related to climate change, resource use and consumption and sustainable production. Many public authorities in the EU have implemented action plans not only for GPPs, but also for sustainable public procurement (SPPs), which addresses environmental, economic and social issues. It is also evident that sustainable ecological procurement takes into account both environmental and societal impacts (Ho, Dickinson and Chan, 2010; Meehan and Bryde, 2011); Grandia, et al., 2014). In 2003, the European Commission encouraged Member States to develop their National Action Programs (NAPs) for greening public 
procurement. They must contain an assessment of the existing situation and of the ambitious goals for the next three years, specifying what measures will be taken to achieve them. Romania, along with Estonia, Hungary, Greece and Luxembourg are the EU states that had not adopted the NAP until May 2017 (European Commission, 2018).

The transition to the green economy is promoted by a mix of policies that are interconnected and that together induce and project the associated structural changes (Blazejczak, et al., 1999). Therefore, the implications of green procurement must be analysed in the context of the other policies used to structure and manage the transition to the green economy. Jacob, Quitzow and Bär (2015) classify ecological policy instruments into market-based instruments (marketing rights, environmental taxes, taxes and storage systems, elimination of subsidies affecting the environment, etc.) and market creation tools (green procurement, direct promotion of demand, indirect promotion of technologies or ecological sectors, promotion of export, etc.). The use of market-based instruments leads to a trend of control to be supplemented by more specific instruments (Jänicke, 2012).

Climate change, air pollution and the degradation of basic natural resources directly or indirectly affect all economic sectors and can influence long-term economic growth (OECD, 2016). Green procurement has a positive impact on: sustainable objectives; innovation; public financial savings; the challenges of the evolving environment, for example, to reduce greenhouse gas emissions and the circular economy (Min and Galle, 2005; European Commission, 2016). Jacob, et al. (2015) argue that green procurement leads to effective competition based on transparency between suppliers of organic products and technologies and avoiding unilateral preferences for certain suppliers. In some works, the special role of green procurement in promoting environmentally friendly innovations in Europe is emphasized (Edler and Georghiou, 2007). Therefore, EPAs are an important tool for achieving the objectives of environmental policy if one considers the importance of public sector expenditure on goods and services in Europe, which represents 14\% of GDP (European Commission, 2016). EPA stimulates employment in the industrial sector, especially in small and medium-sized enterprises, by developing and promoting clean technologies on the market and practicing organic farming contributes to the revitalization of rural space, by creating new jobs (Cazan, 2014).

Both public and private sector organizations implement purchasing practices that include environmental and social considerations. In the private sector, green procurement is considered as a means of improving their products and operations from an environmental perspective in order to reduce the risk, the total cost and the improvement of the supply chain performance. Private sector organizations have become increasingly environmentally responsible in the context of improving the legislative framework (Zhu, Sarkis and Geng, 2009) and have adopted green procurement practices for specific products in the last two decades. It also pays attention to the purchase of the factors of production, respectively the materials and chemicals that are transmitted in the products and services offered.

\subsection{Theoretical context for analysing the connection between green public procurement and the labor market}

The implications of adopting ecological acquisitions on the economy and on the labor market are analysed in the specialized literature in the context of the mix of ecological policies that contribute to the ecological growth. A transition to green growth can create 
opportunities for workers if the challenges associated with this transition are well coordinated to lead to the concomitant improvement of the environment and economic growth. The transition to the green economy through green procurement involves structural transformations of production and consumption throughout the economy as a result of the introduction of new technologies that promote economic activities with reduced impact on the environment and more efficient in terms of resource utilization (Château, Saint-Martin and Manfredi, 2011; OECD, 2017). This economic transformation will involve a reconfiguration of the labor market that creates new opportunities but also employment risks for workers, determined by the changes occurring in the level and composition of the demand for labor both in sectors of activity, in regions and categories of workers. The net effect of green policies on employment is difficult to measure, but the creation and global destruction of jobs throughout the economy tends to have a similar dimension if green policies are well implemented (OECD, 2017). Chateau, Bibas and Lanzi (2018) and Hafstead and Williams (2018) argue that environmental regulations rather influence the sectoral and geographical distribution of employment opportunities and less employment levels at the national level. Also, the Institute for Policy Integrity (2017) argues that the negative effects on employment are relatively smaller compared to the public health benefits. Cao, Wang and Ying (2017) conclude that the implementation of environmental regulations has both direct and mediated impact on employment, respectively the direct impact is positive and the mediated impact is, on the one hand, positive as a result of industrial improvement, and on the other negative part, due to the effects of technological innovation. The introduction of environmental criteria in procurement procedures contributes to the creation of jobs in the ecological economic sectors but also to the destruction of others in high pollution sectors, the effects on employment in these sectors being significant (OECD, 2017). Vona, et al. (2015) suggest based on an empirical analysis that environmental regulation triggers technological and organizational changes that increase the demand for technical, engineering and scientific skills. In the context of tightening the environmental policy, the most productive companies have a temporary boost in productivity growth, while the least productive ones experience a slowdown in productivity (Albrizio, Kozluk and Zipperer, 2017).

The success of adopting green procurement depends on the ability of companies and workers to adapt to the changes in the economic structure induced by them. The distributional influences of the structural changes determined by the implementation of this instrument must be well analysed and forecasted because, otherwise, they may undermine its political acceptability. The labor market and distributive issues are key dimensions for understanding the barriers to implementing green policies, as they can have an effect on the distribution of income on labor, as a result of: 1. existing rigidities in labor markets and 2. different impact on the categories of sectors and jobs (Chateau, Bibas and Lanzi, 2018). Chateau, et al. (2011) argue that labor market imperfections affect policy costs as a percentage of GDP in two ways: by introducing additional costs due to high unemployment and the double dividend effect when carbon taxes are recycled so as to reduce distorted taxes on labor income. The identification of workers who are more vulnerable in terms of employment and wage loss, in the context of applying environmental policies, is a fundamental step in designing the appropriate education and training policies and the redistribution schemes corresponding to the objectives of green growth. Decision makers who want to minimize changes in sectoral employment should prefer performance standards and not environmental taxes (Hafstead and Williams (2018). For all the 
environmental policies considered, low-skilled workers will be more affected, in generally, in terms of job rotation or salary income than the other categories of workers (Chateau, Bibas and Lanzi, 2018).

Some authors argue that active labor market policies largely cover the possible undesirable effects of implementing green instruments, and additional measures should be taken only to increase the efficiency of their application (OECD, 2017). Other authors argue that structural change induced, ecologically or otherwise, should be accompanied by active labor market policies (Bowen, 2012). The proper functioning of the labor market depends to a large extent on the correspondence of the skills, training and qualifications of the workers with the demands of the employers, since the deepening of their non-correspondence increases the costs for the employer, worker and society in general (Paşnicu, 2019). Among the policies with positive impact on employment that should accompany the adoption of this instrument are: the use of government funds obtained from environmental taxes to reduce labor taxes; mitigating the consequences of unwanted distribution and financing vocational education and training programs (OECD, 2017). In the literature, the effects of green political instruments on employment are called green jobs (Jacob, et al., 2015). The term "green" jobs refers to employment in a limited set of industries providing environmental services. Green procurement supports the creation of green jobs, especially in the sectors where public buyers represent a large share of the market, respectively in construction, health services or transport (European Commission, 2016).

\section{Methodological approach}

A balanced, flexible labor market, which allows workers a smooth and short-term transition between economic sectors, plays an important role in the successful adoption of green procurement, otherwise this could lead to the failure of this policy implementation. The transition to the green economy can aggravate the correspondence of qualifications in the labor market if policies, instruments are not properly designed and implemented. McGowan and Andrews (2015) suggest that lack of qualifications and over-qualification are associated with lower labor productivity as a result of less efficient allocation of resources. In the study $(\mathrm{OECD}, 2017)$ it is mentioned that no conclusive conclusions can be drawn unless the labor market indicators are taken into account given the complex link between the economic indicators and the effects on employment.

\subsection{Objectives and indicators used}

Within this section we set out to identify the implications of green procurement on the Romanian labor market in the context of the transition to the green economy. In this respect, we have investigated the main trends of the labor market, current and future, from the point of view of employment on socio-economic dimensions and of the labour demand on the main occupations; we identified a causal relationship between environmental protection expenditure and green jobs, based on the available statistical data, and we surprised the similarities and differences between EU28 countries on green markets and resource efficiency through the green jobs created.

For the three specific objectives, a series of indicators have been identified, which are mentioned (table no.1). The data sources for the selected indicators are: EUROSTAT (2007-2017); CEDEFOP (2019); survey of SMEs Flash Eurobarometer 381 (2013) on the 
topic, resource efficiency and ecological markets. The survey was conducted on 11207 SMEs from 28 EU Member States, of which 402 SMEs from Romania. (Table no. 1)

Table no. 1. Indicators for analysing the implications of green procurement on the Romanian labor market in the context of the transition to the green economy

\begin{tabular}{|c|c|c|c|c|}
\hline Dimensions & Cod & Indicator name & Year & Data source \\
\hline \multirow{5}{*}{$\begin{array}{l}\text { Current trends of } \\
\text { the labor market } \\
\text { by socio-economic } \\
\text { dimensions and } \\
\text { forecasts } \\
\text { regarding } \\
\text { employment and } \\
\text { demand for work }\end{array}$} & 1.1 & $\begin{array}{l}\text { Employment rate by large age groups } \\
(\%)\end{array}$ & $\begin{array}{l}2007- \\
2017\end{array}$ & EUROSTAT \\
\hline & 1.2 & $\begin{array}{l}\text { Employment rate by residence area } \\
(\%)\end{array}$ & $\begin{array}{l}2009- \\
2017 \\
\end{array}$ & EUROSTAT \\
\hline & 1.3 & Over-qualification rate $(\%)$ & $\begin{array}{l}2007- \\
2017\end{array}$ & EUROSTAT \\
\hline & 1.4 & $\begin{array}{l}\text { Increase of employment by sectors of } \\
\text { activity }(\%)\end{array}$ & $\begin{array}{l}2016- \\
2030\end{array}$ & CEDEFOP \\
\hline & 1.5 & $\begin{array}{l}\text { The demand for total jobs, new/lost } \\
\text { and replaced in Romania by } \\
\text { occupation (thousands) }\end{array}$ & $\begin{array}{l}2016- \\
2030\end{array}$ & CEDEFOP \\
\hline \multirow{2}{*}{$\begin{array}{l}\text { The correlation } \\
\text { between the } \\
\text { protection of the } \\
\text { environment and } \\
\text { the green jobs }\end{array}$} & 2.1 & $\begin{array}{l}\text { Public sector } \\
\begin{array}{l}\text { expenditure } \\
\text { environmental } \\
\text { protection } \\
\text { billion) }\end{array}\end{array}$ & $\begin{array}{l}2002- \\
2013\end{array}$ & EUROSTAT \\
\hline & 2.2 & $\begin{array}{l}\text { Green jobs, full-time equivalent } \\
\text { (thousands) }\end{array}$ & $\begin{array}{l}2002- \\
2013\end{array}$ & EUROSTAT \\
\hline \multirow{7}{*}{$\begin{array}{l}\text { SMEs' opinions } \\
\text { and behaviours } \\
\text { regarding green } \\
\text { markets and } \\
\text { resource efficiency }\end{array}$} & 3.1 & $\begin{array}{l}\text { Satisfaction with the return on } \\
\text { investments made in terms of resource } \\
\text { efficiency (\% of those who were } \\
\text { totally dissatisfied) }\end{array}$ & 2013 & $\begin{array}{l}\text { Flash } \\
\text { Eurobarometrul } \\
\text { nr. } 381\end{array}$ \\
\hline & 3.2 & $\begin{array}{l}\text { The company made a bid for a public } \\
\text { procurement auction that includes } \\
\text { environmental requirements (\% of } \\
\text { those who did not) }\end{array}$ & 2013 & $\begin{array}{l}\text { Flash } \\
\text { Eurobarometru } \\
\text { nr. } 381\end{array}$ \\
\hline & 3.3 & $\begin{array}{l}\text { The type of assistance that the } \\
\text { company relies on to be more resource } \\
\text { efficient (\% of those based on their } \\
\text { own resources) }\end{array}$ & 2013 & $\begin{array}{l}\text { Flash } \\
\text { Eurobarometru } \\
\text { nr. } 381\end{array}$ \\
\hline & 3.4 & $\begin{array}{l}\text { Public support for resource efficiency } \\
\text { actions (\% of those who are totally } \\
\text { dissatisfied) }\end{array}$ & 2013 & $\begin{array}{l}\text { Flash } \\
\text { Eurobarometru } \\
\text { nr. } 381 \\
\end{array}$ \\
\hline & 3.5 & $\begin{array}{l}\text { The company offers green products or } \\
\text { services ( } \% \text { of those who do not offer } \\
\text { green products or services) }\end{array}$ & 2013 & $\begin{array}{l}\text { Flash } \\
\text { Eurobarometru } \\
\text { nr. } 381 \\
\end{array}$ \\
\hline & 3.6 & $\begin{array}{l}\text { The main reasons why the company } \\
\text { does not offer green products and } \\
\text { services (\% of those who indicated the } \\
\text { lack of public support) }\end{array}$ & 2013 & $\begin{array}{l}\text { Flash } \\
\text { Eurobarometru } \\
\text { nr. } 381\end{array}$ \\
\hline & 33.7 & $\begin{array}{l}\text { Full-time workers working in green } \\
\text { jobs }(\% \text { of those who indicated } 0 \text { green } \\
\text { workers) }\end{array}$ & 2013 & $\begin{array}{l}\text { Flash } \\
\text { Eurobarometru } \\
\text { nr. } 381 \\
\end{array}$ \\
\hline
\end{tabular}

Source: authors 


\subsection{The method used}

The chosen method for identifying the current trends of the Romanian labor market and the forecasts regarding employment and demand for labor, on socio-economic dimensions, is the analysis on secondary data. In the case of current trends, the analysis is dynamic (20072017) and comparative with the EU28. The rate of over-qualification was calculated by the authors as a ratio between graduates of higher education (ISCED 5-8) engaged in occupations that do not require higher education (ISCO groups 4-9) and employed persons with higher education.

To establish a link between environmental protection spending and green jobs, a regression was made on these data strings, between 2003 and 2013.

The method chosen to explore the perceptions and behaviours of SMEs in EU28 on green markets and resource efficiency was cluster analysis. Cluster analysis is a multivariate analysis technique that includes a number of algorithms for classifying countries into homogeneous groups. The cases were sorted into groups on the criterion that there is a greater similarity between the members of the same group compared to that of the members who are in different groups. The method chosen to calculate the distance between countries was the Euclidean distance, and the average-linkage method was used to measure the similarity between the groups of countries. Following the application of the algorithm in the IBM SPSS 19 program, classification trees (dendograms) were obtained.

\section{Results and discussions}

\subsection{Current labor market trends and forecasts regarding employment and need for work}

In Romania, in 2017, the employment rates of young people (20-29 years old) and the elderly (55-64 years old) continued to be lower than those registered in the EU28 and the total employment rate. In 2017, the employment rate for people in the 20-29 age group was $59.4 \%$, and for the 55-64 age group, $44.5 \%$. The difference from the total employment rate in 2017 was 9.4 p.p. for the age group 20-29 years old, respectively 24.3 p.p. for the 55-64 age group. Lower employment rates for young people, compared to those of the elderly (20-64 years), reflect the less secure position of young people in the labor market, which makes their employment more sensitive to macroeconomic fluctuations than employment among adults. During the analysed period, the gap between the employment rates of the elderly at national level and the EU28 increased, the latter registering a significant increase. In EU28, in 2017 the employment rates of young (20-29 years old) and elderly (55-64 years old) continued to be lower than the total employment rate. In 2017, the employment rate for persons in the 20-29 age group was $63.9 \%$, and for the 55-64 age group, $57.1 \%$. The difference from the total employment rate in 2017 was: 8.3 p.p. for the age group 20-29 years, respectively of 15.1p.p. for the 55-64 age group. With a view to increasing employment among older people, policies no longer encourage early retirement, as in the pre-recession period, and have evolved in the direction of intensifying various forms of slowdown - reduced working time and gradual / phased retirement.

Employment rate by residence area, highlights the impact of population density, in Romania, starting with 2014, the gap of employment rates by residence area registered in 2017 was $5.2 \mathrm{pp}$, the employment rate in the rural area having a lower value compared to 
the urban environment, $67.7 \%$. In EU28, the impact of population density was not obvious, in 2017 , cities and suburbs registered an employment rate of $72.0 \%$, and in rural areas of $72.6 \%$.

The share of over-qualified persons in Romania in 2017 was $17.7 \%$ of the total of the graduates of higher education (ISCED 5-8), representing 314.4 thousand persons with higher education who worked in occupations below their level of qualification. In the analysed period, 2007-2017, their share increased by 9p.p, and their number tripled. In EU28, in 2017, the share of over-qualified persons was $22.7 \%$ of the total of the graduates of higher education (ISCED 5-8), representing 17.8 million people with higher education who worked in occupations below their level of qualification. Their share increased in the period $2007-2017$ by $1.9 \%$.

In 2016-2030, the largest decline in employment is forecasted in the construction sector, followed by the primary sector (agriculture and extractive industry) and utilities. The biggest increases are expected in professional services, public services (health, social care and education, public and defence sector), art and recreation, as well as administrative services. In sectors with the potential to create green places, such as: organic agriculture (including organic farms); sustainable construction; sustainable forests; public transport; renewable energy; waste recycling and management; industry of cleaning products and government activities, employment could see an improvement as a result of increased demand for these products in the context of implementing green procurement. (Figure no. 1)

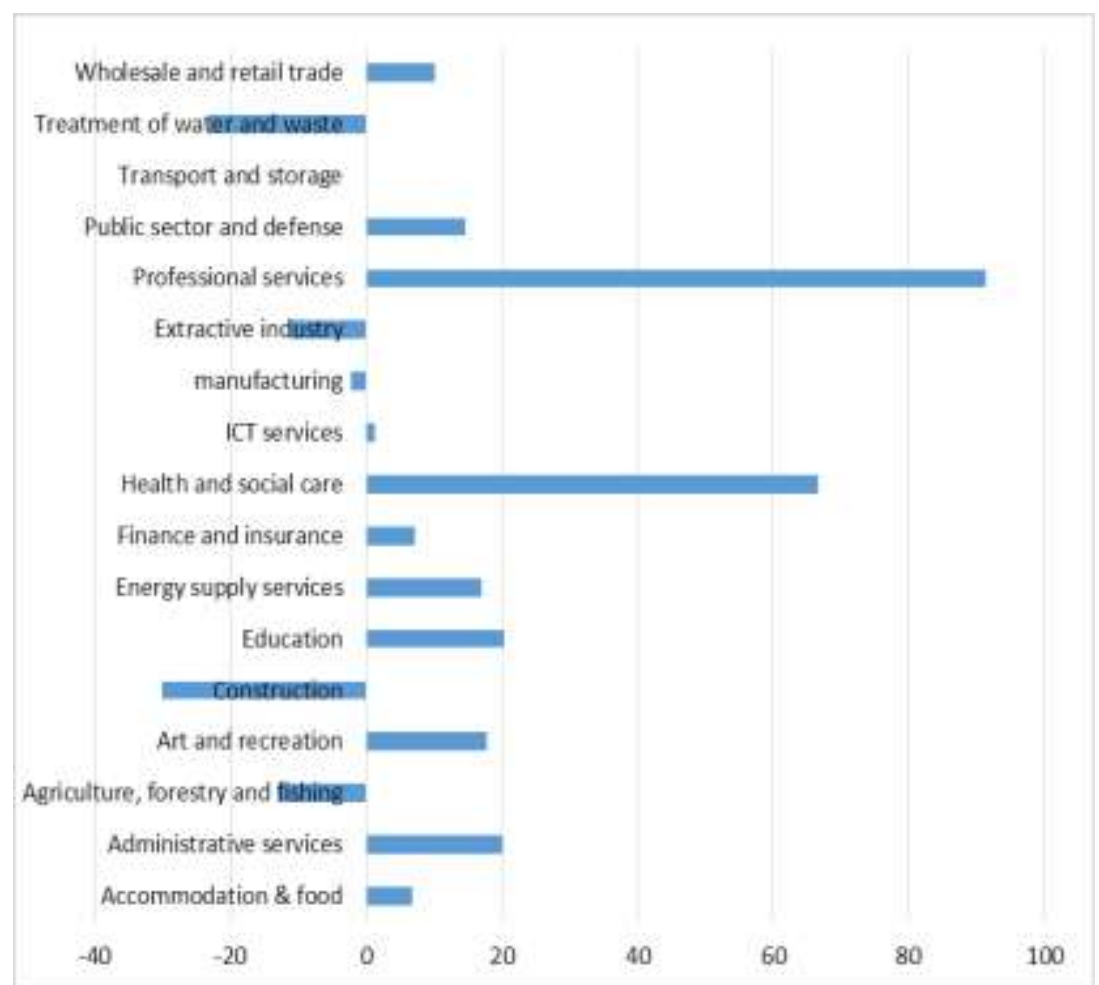

Figure no. 1: Employment growth in Romania by activity sectors, 2016-2030 (\%) Source: CEDEFOP (2019) 
The demand for jobs was determined by the sum of the jobs lost / newly created and those resulting as a result of the replacement of persons, in particular as a result of retirement. Most jobs will arise from the need to replace workers who retire or change their jobs. The occupational groups in which the highest demand for jobs is expected are the professionals and the skilled workers in agriculture and fisheries. Within the two occupational groups it can be observed that, while in the professional sector the difference between the newly created jobs and the terminated jobs is positive, for the professional group "farmers and related workers" it will be negative, most jobs resulting from the request to replace the persons leaving the occupation. The jobs in these occupational groups are expected to represent $21 \%$ and $26 \%$ of the total jobs, respectively, by 2030 . Another occupational group in which the demand for jobs is forecast to increase as a result of the demand for replacement, given the existence of a negative difference between the newly created and the terminated jobs, it is that of the "skilled workers". (Figure no. 2)

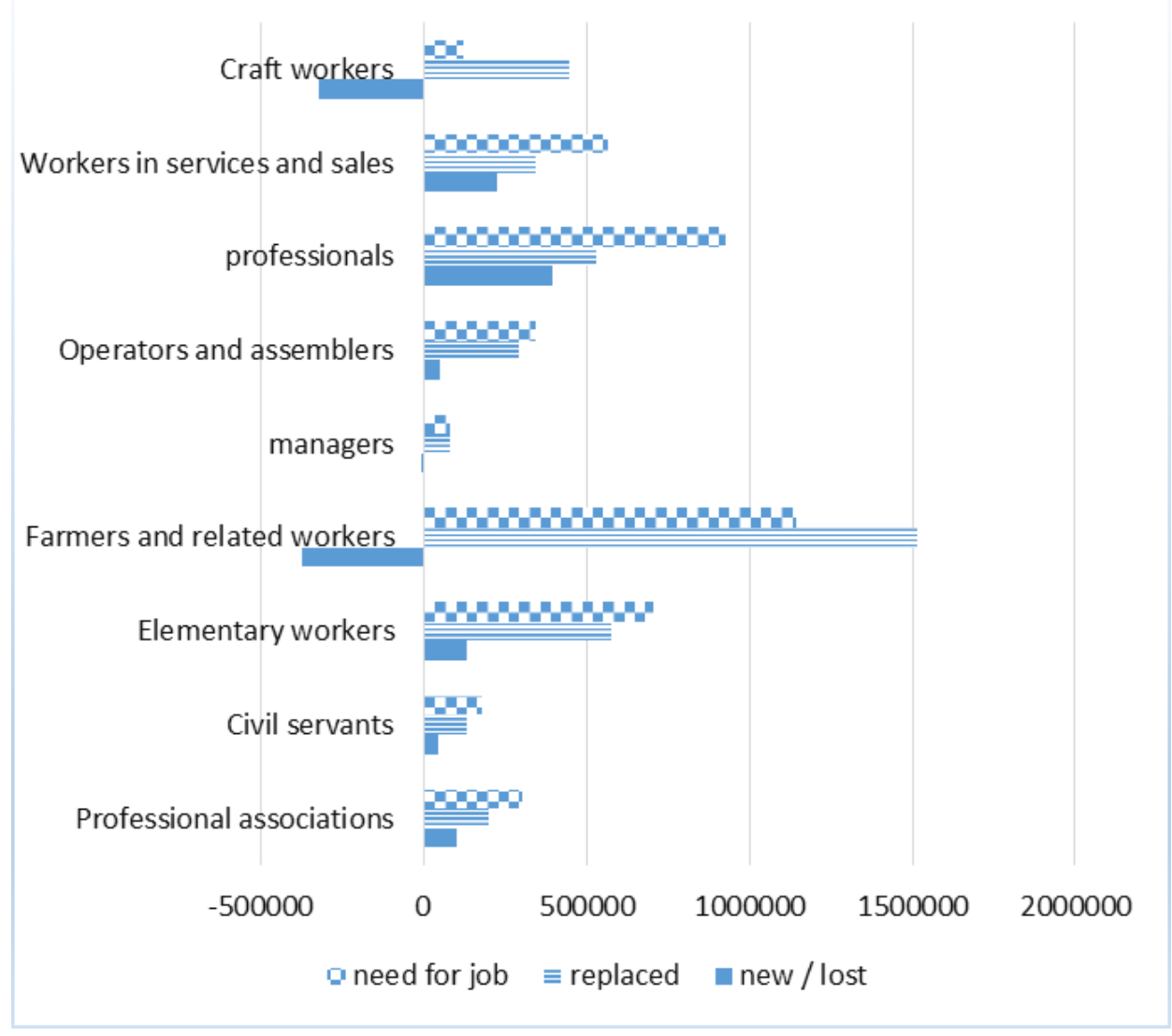

Figure no. 2: Demand for jobs in Romania by occupations and source of origin, in the period 2016-2030 (thousands of persons)

Data Source: CEDEFOP (2019) 


\subsection{The correlation between the expenses with the protection of the environment and} the green jobs

In the following chart we have represented the number of green jobs, equivalent full time (in thousands), according to the expenses for environmental protection, expressed in billions of euros, for EU 28, between 2003 and 2013. The axes have been shortened, starting from 60 or 3000 respectively to improve reading. To understand the trend, or the link between these two variables, a regression was made on these two data strings. The result obtained is represented by a dashed line. The existence of a positive relationship between the two variables suggests that an increase in spending for environmental protection will result in an increase in green jobs. This is evidenced by the coefficient 0.0192 which is positive and statistically representative at $\mathrm{p}=0.95$, or $95 \%$. Finally, $\mathrm{R}^{2}$ of about 0.68 gives the regression an extra robustness, representing the data in a satisfactory percentage. (Figure no. 3)

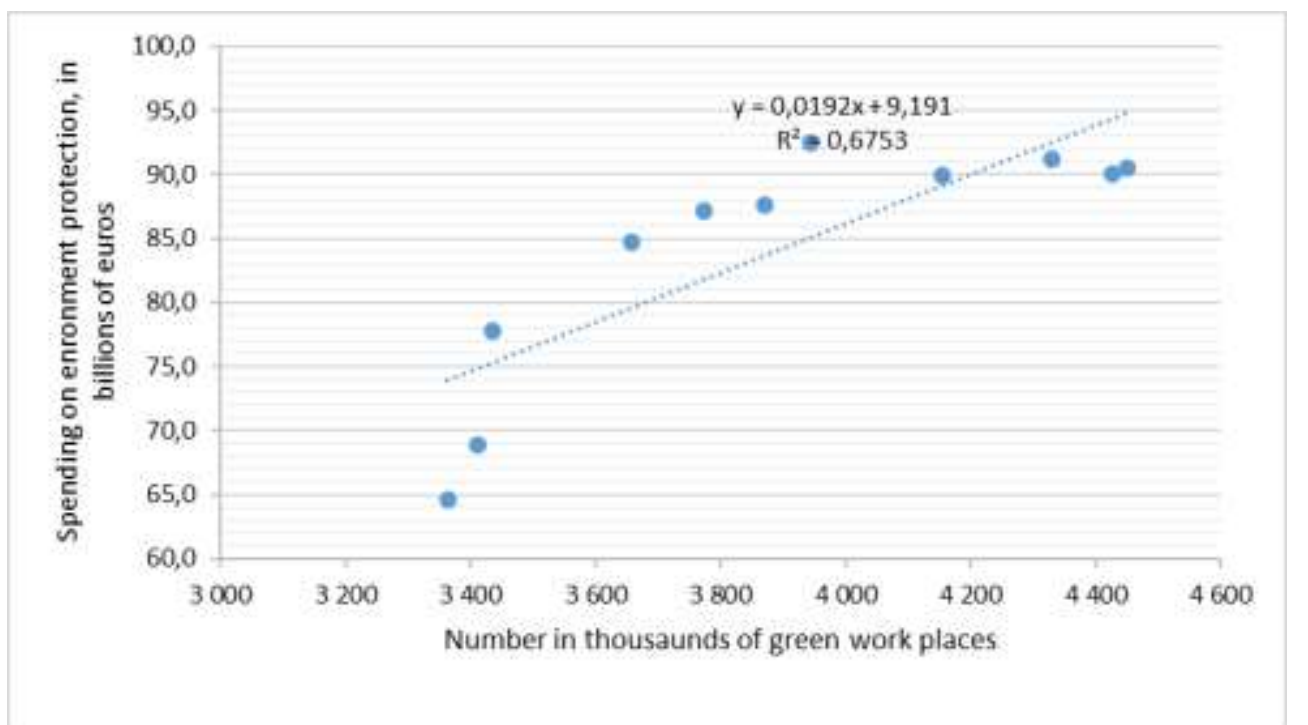

Figure no. 3: Correlation between public sector expenditure with environmental protection and green jobs, EU28, 2003-2013

Source: EUROSTAT (cod online: nama_10_gdp, env_ac_egss1)

\subsection{SMEs' opinions and behaviours regarding green markets and resource efficiency}

It is noted that the countries are grouped into two groups, which shows that there were no significant differences between the countries, in 2013, regarding ecological markets and resource efficiency. The first group, in which most of the EU28 countries are located (22 countries), includes the countries with the lowest share of SMEs that have declared themselves totally dissatisfied with the efficiency of the investments in the efficiency of the resources (United Kingdom, Holland), the share the smallest of the companies that did not participate in a public bidding that includes environmental requirements (Sweden, Great Britain), the smallest percentage of SMEs that were totally dissatisfied with the public support for resource efficiency (Estonia and Great Britain) but also the largest share of SMEs that have declared zero green workers (Estonia, Malta). Romania, although part of 
the first group, stands out by the large share of SMEs that have never made an offer for a public bidding that includes environmental requirements $(90 \%)$ and which are based on their own resources in the effort of resources efficiency (87\%). The second group (Italy, Hungary, Bulgaria, Portugal and Greece) comprises countries with the highest percentage of SMEs that do not offer green products or services (Hungary) and the lowest share of SMEs that used own resources in resource efficiency (Italy). Croatia is distinguished from the two groups, being seconded to extremes, in the case of those who rely on their own resources $(91 \%)$ and far below the average for those who indicated zero green workers (4\%). (Figure no. 4)

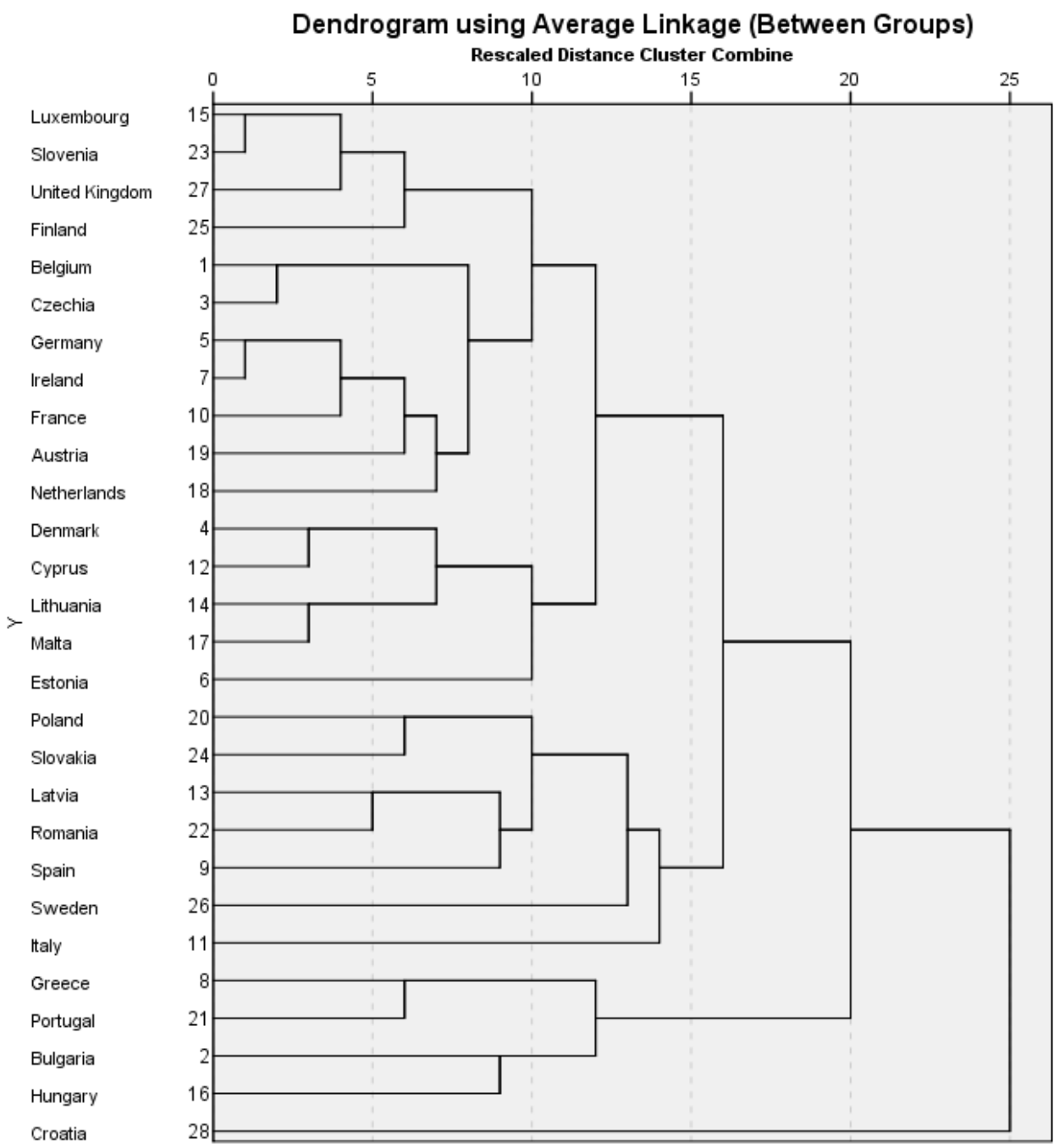

Figure no. 4: Groups of countries according to indicators that describe opinion and behaviours SMEs on green markets and resource efficiency 


\section{Conclusions}

The purpose of the article is to contribute to a better understanding of the implications of the transition to the ecological economy through green procurement on the Romanian labor market in order to identify ways of action for its better functioning.

The methods used to achieve this objective were: secondary data analysis of current trends in the Romanian labor market by socio-economic dimensions and forecasts regarding employment by activity sectors and labor demand by occupations; a regression analysis between public spending on environmental protection and green jobs and a multivariate cluster-type analysis to explore the perceptions and behaviours of SMEs in EU28 on green markets and resource efficiency.

The results highlight the implications of green procurement on the labor market in the context of the transition to the ecological economy from the point of view: theoretically, managerially, as well as the limits and perspectives. From a theoretical point of view it is highlighted: a) certain structural imbalances in the labor market in the participation of young, old and rural people, as well as a deficient correspondence of the educational offer with the demands of the labor market as a result of the significant increase of the above rate -qualification; b) the significant increase of employment in sectors such as professional and health and social care services, as well as the negative demand for work through the prism of new / lost jobs for agricultural workers and tradesmen, during 2016-2030; c) a positive relationship between the two variables subjected to regression analysis, suggesting that an increase in expenditure for environmental protection will result in an increase in green jobs. From a managerial point of view, the grouping of the EU28 countries on two clusters suggests that there are no significant differences between countries depending on the functioning of ecological markets and resource efficiency. There are a number of limitations of the study stemming from the lack of detailed statistical data regarding the implementation of green procurement, respectively of ecological policies in general, as well as the actuality of the existing ones. Further research is needed to quantify all employment dimensions that could be influenced by implementing green procurement. The challenges of the labor market could be transformed into opportunities through multidimensional and innovative approaches, such as streamline active measures and increasing the level of education and training of the workforce, especially in the rural area.

\section{Bibliography}

Albrizio, S., Kozluk, T., Zipperer, V., 2017. Environmental policies and productivity growth: Evidence across industries and firms. Journal of Environmental Economics and Management, [e-journal] 81(C), pp.209-226.

Bowen, A., 2016. Green Growth, Green Jobs and Labor Markets. World Bank Policy Research Working Paper No. 5990. [pdf] Available at: <https://ssrn.com/ abstract=2018164> [Accessed 1 August 2019].

Blazejczak, J., Edler, D., Hemmelskamp, J., Jänicke, M., 1999. Environmental Policy and Innovation - An International Comparation of Policy Frameworks and Innovation Effects'. In: Klemmer, P. (Ed). Innovation Effects on Environmental Policy Instruments. Analytica, Berlin, pp.9-30. 
Cao, W., Wang, H., Ying, H., 2017. The Effect of Environmental Regulation on Employment in Resource-Based Areas of China - An Empirical Research Based on the Mediating Effect Model, International Journal of Environmental Research and Public Health, [e-journal] 14(12), pp.1-11.

Cazan, R., 2014. Achiziţii publice ecologice în România - protecţia mediului prin cheltuieli publice responsabile. [pdf] Programul de Cooperare Elvețiano-Român. Available at: $<$ https://www.ecopolis.org.ro/media/Achizitii\%20publice\%20ecologice\%20in\%20roma nia-final.pdf $>$ [Accessed 11 July 2019].

CEDEFOP, 2019. 2018 skills forecast Romania. [pdf] CEDEFOP. Available at: <https://www.cedefop.europa.eu/files/cedefop_skills_forecast_2018_-_romania.pdf>. [Accessed 11 July 2019].

Château, J., Saint-Martin, A., Manfredi, T., 2011. Employment impacts of climate change mitigation policies. In: A General-Equilibrium Perspective. [online] OECD iLibrary. Available at: <https://www.oecd-ilibrary.org/docserver $/ 5 \mathrm{~kg} 0 \mathrm{ps} 847 \mathrm{~h} 8 \mathrm{q}$-en.pdf?expires= $1569318947 \& \mathrm{id}=\mathrm{id} \&$ accname $=$ guest $\&$ checksum $=7 \mathrm{E} 0288 \mathrm{C} 90 \mathrm{C} 0 \mathrm{~A} 67591048 \mathrm{C} 2873 \mathrm{AF} 4$ 002A> [Accessed 11 July 2019].

Château, J., Bibas, R., Lanzi, E., 2018. Impacts of green growth policies on labour markets and Château wage income distribution: a general equilibrium application to climate and energy policies. [online] OECD iLibrary. Available at: <https://www.oecdilibrary.org/docserver/ea3696f4-en.pdf?expires $=1569844710 \& i d=i d \&$ accname $=$ guest $\&$ checksum=01A6D34A4357991570D0FDBA9BB06749> [Accessed 15 July 2019].

Comisia Europeană, 2016. Achiziții ecologice. Manual privind achizițiile publice ecologice, Ediția a treia. [pdf] Bruxelles: Comisia Europeană. Available at: <https://ec.europa.eu/ environment/gpp/pdf/handbook_2016_ro.pdf> [Accessed 11 July 2019].

Comisia Europeană, 2008. Comunicarea Comisiei către Parlamentul European, Consiliu, Comitetul Economic și Social European și Comitetul Regiunilor cu privire la achiziţii publice pentru îmbunătățirea condițiilor de mediu, COM(2008) 400 final.

Elder, J., Gheorghiou, L., 2007. Public procurement and innovation-Resurrecting the demand side. Research Policy, [e-journal] 36, pp.949-963.

European Commission, 2018. National GPP Action Plans. [pdf] Bruxelles: European Commission. Available at: <https://ec.europa.eu/environment/gpp/pdf/GPP_NAPs_ June_2018.pdf $>$ [Accessed 12 July 2019].

Grandia, J., Groeneveld, S., Kuipers, B., Steijn, B., 2014. Sustainable Procurement in Practice: Explaining the Degree of Sustainable Procurement from an Organisational Perspective. In: Decarolis F., Frey M. (Eds.). Public Procurement's Place in the World. Central Issues in Contemporary Economic Theory and Policy. Palgrave Macmillan, London, pp.37-72.

Hafstead, M., Williams, R., 2018. Unemployment and environmental regulation in general equilibrium. Journal of Public Economics, [e-journal] 160(C), pp.50-65.

Ho, L.W.P., Dickinson, N. M., Chan, G.Y.S., 2010. Green procurement in the Asian public sector and the Hong Kong private sector. Natural Resources Forum, 34(1), pp.24-38.

Institute for Policy Integrity (IPI), 2017. Does Environmental Regulation Kill or Create Jobs?, New York University School of Law. Institute for Policy Integrity. [pdf] Available at: 〈https://policyintegrity.org/files/media/Jobs_and_Regulation_Factsheet.pdf> [Accessed 28 July 2019]. 
Jacob, K., Quitzow, R., Bär, H., 2015. Green Jobs Impacts of a Green Economy on Employment. [pdf] Deutsche Gesellschaft für Internationale Zusammenarbeit (GIZ). Available at: <https://www.greengrowthknowledge.org/sites/default/files/downloads/ resource/Jacob,\%20Quitzow,\%20B\%c3\%a4r\%202014\%20Green\%20Jobs_ENGLISH. pdf> [Accessed 5 July 2019].

Janicke, M., 2012. Green Growth: From a Growing Eco-Industry to Economic Sustainability. Energy Policy, [e-journal] 48, pp.13-21.

McGowan, M.A., Andrews, D., 2015. Labour Market Mismatch And Labour Productivity: Evidence From Piaac Data. Paris: OECD.

Meehan, J., Bryde, D., 2011. Sustainable Procurement Practice. Business Strategy and the Environment, 20(2), pp.94-106.

Min, H., Galle, P., 2005. Green Purchasing Strategies: Trends and Implications. Journal of Supply Chain Management, 3, pp.10-17.

OECD, 2016. The Economic Consequences of Outdoor Air Pollution. [pdf] Paris: OECD Publishing. Available at: <https://www.oecd.org/environment/indicators-modellingoutlooks/Policy-Highlights-Economic-consequences-of-outdoor-air-pollution-web.pdf $>$ [Accessed 5 July 2019].

OECD, 2017. Employment Implications of Green Growth: Linking jobs, growth, and green policies. [pdf] OECD Publishing. Available at: <https://www.oecd.org/environment/ Employment-Implications-of-Green-Growth-OECD-Report-G7-EnvironmentMinisters.pdf> [Accessed 5 July 2019].

Paşnicu, D., 2019. The role of the education system in solving the skills mismatches on the labor market. International Conference on Education and New Developments, vol II, pp.312-314.

Vona, F., Marin, G., Consoli, D., Popp, D., 2015. Green skills. [pdf] NBER Working Paper 21116. Available at: <https://www.nber.org/papers/w21116.pdf> [Accessed 20 July 2019].

Zhu, Q., Sarkis, J., Geng, Y., 2009. Green supply chain management in China: pressures, practices and performance. International Journal of Operations \& Production Management, 25(5), pp.449-468. 